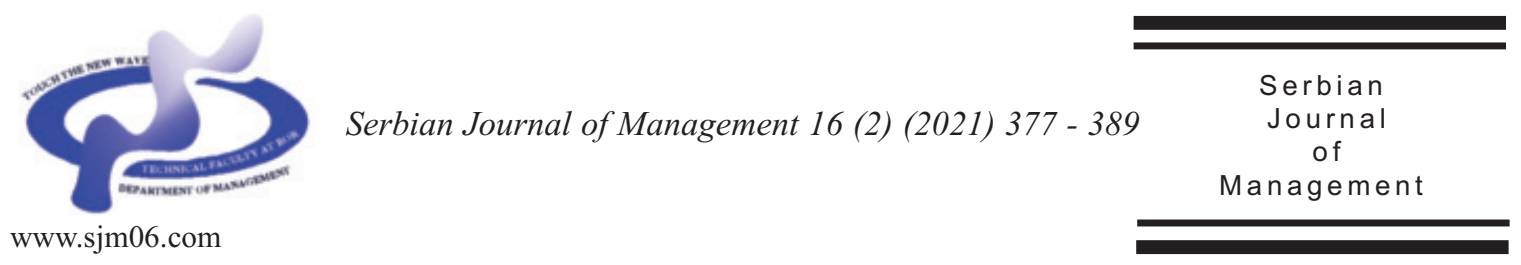

\title{
THE INTERDEPENDENCE BETWEEN DEVELOPING AND DEVELOPED STOCK MARKETS: THE CASE OF THE MACEDONIAN, BELGRADE, SIX SWISS AND EURONEXT PARIS STOCK EXCHANGE
}

\author{
Dusica Stevcevska Srbinoska*, Jadranka Mrsik, Egor Sekuloski and Tome Nenovski \\ University American College Skopje, School of Business Economics and Management, \\ Boulevard III Makedonska Brigada 60, 1000 Skopje, North Macedonia
}

(Received 12 May 2020; accepted 08 June 2021)

\begin{abstract}
The aim of the paper is to examine the level of interdependence between developing and developed stock markets. The correlation of the Macedonian (MBI10) stock exchange index with the Belgrade (BELEX15), the Six Swiss (SLI) and the Euronext Paris (CAC40) stock exchanges from November 2005 to October 2018 was studied. In order to assess the impact of the crisis on the interrelations between these equity markets, the analyzed period was we subdivided into three segments (pre-crisis, during crisis and post-crisis) and the data sets were subjected to linear regression analysis. The research results indicate an increased correlation of the Macedonian with Belgrade and Euronext Paris Stock Exchanges and decreased correlation with Six Swiss during the time of financial distress comparing to pre and post crisis periods. The findings of this study contribute to the overall picture of the relationship between stock markets in the time of Financial Crisis. Moreover, by investigating the interrelationship between developing and developed European stock markets, the results suggest that financial market integration is time-varying.
\end{abstract}

Keywords: MSE, European stock exchanges, financial crisis, diversification

\section{INTRODUCTION}

The stock exchanges are becoming increasingly globalized as new centers of economic strength and innovation develop around the world (IPO Insights, 2009). The globalization may improve market

\footnotetext{
* Corresponding author: dusica@uacs.edu.mk
}

DOI: $10.5937 /$ sjm16-26552 efficiency, lower its risk due to the possibility of diversification, and use arbitrage in a relevant way. However, it may also increase pricing volatility and trading instability, due to the high correlation between leading - major- stock markets and other markets as well as to the fact that the 
irrational trading in one market may move to other markets as witnessed in the last two decades (Sharma, 2011; Chand \& Thenmozhi, 2013; Alomari et al., 2018; Srikanth \& Aparna, 2017; Samadder \& Bhunia, 2018). The Global Financial Crisis (2008) has caused high turbulence in the financial markets and also widespread economic slowdown across the globe (Dhal, 2009). This situation has utterly baffled many economists with a lot of questions regarding the level of impact the Crisis has on the international financial integration.

According to Liu (2013) several mechanisms influence interrelation between developed and developing markets: (i) information capacity and industrial structure similarity, (ii) economic integration and (iii) financial integration that is important only within the same group of developed or developing markets and not between those two groups. Analyzing the stock market convergence of all EU countries, PWC (2015) explain that a perfectly integrated market would imply the absence of profitable arbitrage and should respond to shocks in a similar way. The results from the analyses indicate increased correlations of stock market returns for EU countries compared to returns of the benchmark country over time, showing that stock markets are becoming increasingly connected to each other. Greece and Spain, have shown decreased integration and the Czech Republic, Hungary, Slovakia, Estonia and Slovenia have shown increased convergence.

The Macedonian Stock exchange is relatively a young and embryonic exchange with low level of liquidity and market depth. The Exchange was highly impacted by foreign investors in the pre- crisis period given their participation of almost $40 \%$ in its turnover in 2008 , only to see them withdraw from the market in the aftermath of the crisis. The high turnover of foreign investors contributed significantly for increasing the overall turnover and the stock prices of the Macedonian stock exchange. The main stock index MBI10 increased by $905 \%$ in the period from 2005 to 2007, dropping in 2011 by $75 \%$ from its highest value. And the period of recovery of the Stock exchange was slow and long comparing to other developing and developed stock exchanges and at the end of 2019 it is still only $53.78 \%$ of its highest value in 2007.

Investing in foreign securities is an additional opportunity for the local investors and understanding the direction of movement of stock prices on different stock exchanges is important for making investment decisions (Eiling et al., 2012; Garcia et al., 2014). Our study focuses on the relationship between two developing (Macedonian Stock Exchange and Belgrade Stock Exchange,) and developing and developed stock exchanges (Macedonian Stock Exchange with Euronext Paris and Six Swiss Stock Exchange). In order to evaluate the relationship between those markets, the monthly values of their main indices (MBI10, BELEX15, CAC40, SLI) from November 2005 to October 2018 were collected, processed and analyzed with statistical models. To the best of our knowledge, this paper differs from other related studies in a way that it investigates the interrelationship between developing and developed European stock markets, clearly suggesting that financial market integration is time-varying.

The rest of the paper is organized in a following manner: The Literature Review section covers the researches of stock exchanges, the 2008 crisis and the 
relationship between stock exchanges. The Data and Methodology section explains the methods of collecting, processing and analyzing the data. The Findings and discussions section provides an overview of the empirical results while contrasting them to the findings of other authors. Lastly, in the Conclusion section we provide a brief overview of the research process and the main results.

\section{LITERATURE REVIEW}

Europe is home of many compelling stock exchange markets. We are witnesses of a noticeable improvement of the European stock exchanges from the time where Pagano et al. (1999) examined the factors that influence the European companies that get listed abroad. Many researches agreed that as more and more countries join the European Union community, the European stock exchanges have higher co-integration and are strengthening their overall appearance. In the early 2000s, Aggarwal et al. (2003) examined the time-varying integration of European equity markets (from 1985 to 2002) using daily data for the main EU countries. This study shows that there was integration in European countries right after the establishment of the Economic and Monetary Union and the European Central Bank. A similar conclusion was reached by Syriopoulos and Roumpis (2009) who examined the relationship between the major Balkan equity markets (Romania, Bulgaria, Croatia, Turkey, Cyprus and Greece) with the developed equity markets (USA and Germany). They concluded that following the EU accession, Balkan countries became gradually more integrated with the developed equity markets. The results of
Kenourgios and Samitas (2011) indicate that the Balkan emerging stock markets have become increasingly integrated with the developed markets (UK, Germany and Greece) and the US stock market during the period from 2000 to 2006.

The research results of Horvath and Petrovski (2012) demonstrate higher correlation degree of Central European (Czech Republic, Hungary, Poland) than of South Eastern Europe countries (Croatia, Macedonia, Serbia) stock markets with developed Western European stock markets. The co-movement of SEE countries with the developed markets was almost at zero level except Croatia which showed a higher degree of integration that the other two stock markets.

The more global research of Tennby and Ringström (2015) analyzes the integration levels of five European stock exchanges (Euronext Paris-CAC40, Euronext Amsterdam-AEX, Euronext BrusselsBEL20, Luxemburg-LuxX and Frankfurt stock exchange-DAX30) with the regional market (STOXX Europe 50) and the world market (MSCI World) from 1999 to December 2014. The results designate that the analyzed markets are becoming more and more integrated with the regional and world market after the inception of the euro. This suggests that it may be challenging for the international investor to detect large diversification options in the EU region.

The work of Kenourgios and Samitas (2011) explores the relationship between Balkan stock markets and the advanced markets and detects a strong and positive association between the Greek and Romanian, Bulgarian, Serbian, Macedonian stock exchanges. The authors also establish that the German stock exchange haa a strong and positive association with the Croatian, 
Turkish and Albanian stock exchanges. Similarly, Şahin (2015) examines the cointegration of three Balkan stock markets (Bosnian, Macedonian and Turkish) with the German stock market. The highest detected correlation is between the Macedonian and Bosnian stock exchanges, while the Turkish stock exchange is much more closely related to the German stock exchange.

The high interrelationship between the Balkan countries stock exchanges is confirmed with numerous researches like the one conducted by Angelovska (2017) which assesses the relationship between the Macedonian and Croatian stock markets in the period from 2005 to 2017 . The results showed that the Macedonian stock exchange is highly influenced by the Croatian stock exchange and that they have bidirectional causality. This implies that there are no possibilities to reach diversification by investing solely in these two stock markets. Comparably, Karagoz and Ergun (2009) investigated the financial integration among five emerging Balkan stock markets (Bulgaria, Croatia, Greece, Romania and Turkey). The results disclosed a relationship of a bidirectional nature between the Balkan stock markets. A few years later, Gradojević and Dobardžic (2013) analyzed the causal relationship between the returns of CROBEX (Croatia), SBI-TOP, (Slovenia), CETOP (Central Europe) and DAX (Germany) indices with the Serbian BELEX15 index, using daily closing data in the period from October 2005 to August 2009. They found out that there was a significant impact of the CROBEX and CETOP indices on the BELEX15 index, while the BELEX15 and SBI-TOP had mutual two-way causation.

Slimane et al. (2013) assessed the impact of the Global Financial Crisis on the relationship of European stock exchange markets (France, Germany and the UK). Using the VAR-EGARCH model they found out that the interrelationship between the analyzed markets was increased to a significant extent during the period of the crisis. These findings suggest that international investors should not invest in European markets if they want to diversify their portfolios.

In the Tudor (2011) research, the relationship between CEE and US stock markets during the crisis was stronger than the relationship before or after the crisis. The increased integration between the emerging and developed stock exchange markets during the crisis was confirmed by the study of Nistor et al. (2012) which explores the relationship between CAC40 (France) index with three CEE countries' indices (Czech Republic- PX index, Hungary-BUX index and Romania-BET-C index) before and during the global crisis. Zdravkovski (2016) examined the effects of the Global Financial Crisis on the integration among the Balkan stock markets (Macedonia, Serbia, Croatia, Slovenia and Bulgaria). The research was conducted with Johansen co-integration test for the period from October 2005 to December 2015 (divided in three subperiods: pre-crisis, during the crisis and postcrisis). He found out that the crisis increased the level of integration in the Balkan markets which means that investors have decreased possibilities to diversify their portfolios in these markets.

\section{DATA AND METHODOLOGY}

\subsection{Sample}

This research is constructed using 
quantitative analysis of collected data from secondary sources (web pages of the relevant stock exchanges and stock trading sites: investing.com and finance.yahoo.com). The data analyzed is consisted of the four selected Stock Exchanges (MSE, Belgrade Stock Exchange, Euronext Paris and Six Swiss Stock Exchange monthly index values expressed in the national currencies in the period from November 2005 to October 2018, divided in three sub-periods: precrisis, during crisis and post-crisis). We have selected these four stock exchanges as representatives of the emerging and developed markets. The four indices (MBI10, BELEX15, CAC40 and SLI) were selected on a "most widely used indicator" basis for the description of the stock exchanges. Table 1 shows the general stock indices of the countries that comprise the sample of this study.

We were interested in the investors response during the normal period (i.e. before crisis) and in the atypical scenarios (during crisis and in the recovery period). The response was analyzed indirectly by the changes in the inter-correlations among the two emerging and the two developed European stock exchanges divided in three data sub-groups.

Our first sub-sample representing the precrisis period contains data from November 2005 to July 2007. There are a lot of different interpretations about the exact onset date of the Global Financial Crisis among the economists. Although it is commonly held that in September 2008 it developed into a full blown international banking crisis with the collapse of the investment bank Lehman Brothers (which triggered global panic and the "economy almost collapsed" according to The Balance, 2019), we followed the studies of Majid and Kassim (2009), Zdravkovski (2016), and Adeyeye et al. (2018) in which it is stated that the roots of the Global Financial Crisis date back to the summer of 2007.

The second sub-sample encompasses the period starting from August 2007 until November 2011 (the economic crisis ended in the Fall of 2011 according to Weisenthal, (2013). This period in which "too big to fail" banks were going bankrupt and many stock exchanges collapsed left a huge scar on the world's economy. The post-crisis sub-sample in our research contains more extensive data to show all the stages of the economy upswing (from December 2011 until October 2018).

\subsection{Hypothesis}

The objective of this study is to analyze the level of integration of Macedonian SE with Belgrade SE, Euronext Paris and Six Swiss SE before, during and after the 2008 Financial crisis. After the review of literature and the obtained results on the existence of correlations between developing and developed stock exchanges in the period

Table 1. Stock Exchanges and Stock Indices

\begin{tabular}{lllll}
\hline No & Country & Stock Exchange & Index & $\begin{array}{l}\text { Index date of } \\
\text { inception }\end{array}$ \\
\hline 1 & Nord Macedonia & Macedonian Stock Exchange & MBI10 & November, 2001 \\
2 & Serbia & Belgrade Stock Exchange & BELEX 15 & September, 2005 \\
3 & France & Euronext Paris & CAC40 & December, 1987 \\
3 & Swiss & Six Swiss Stock Exchange & SLI & July, 2007 \\
\hline
\end{tabular}


of the 2008 Financial Crisis, the following hypotheses were designed:

Hypothesis 1: The correlation between Macedonian SE (represented by MBI10) and Belgrade SE (represented by BELEX15) is higher during the crisis in comparison with the pre- and post-crisis periods.

Hypothesis 2: The correlation between Macedonian SE (represented by MBI10) and Euronext Paris (represented by CAC40) is higher during the crisis in comparison with the pre- and post-crisis periods.

Hypothesis 3: The correlation between Macedonian SE (represented by MBI10) and Six Swiss SE (represented by SLI) is higher during the crisis in comparison with the preand post-crisis periods.

\subsection{Methodology}

For the purpose of this research we applied simple linear regression analysis which includes Pearson correlation (in simple linear regression multiple $\mathrm{R}=$ Pearson correlation coefficient) and Anova test (where in our case Significance F stands for $\mathrm{P}$-value). The simple linear regression is a statistical method that can be used to study the relationship between two continuous (quantitative) variables (Landau \& Everitt, 2004) .

\section{FINDINGS AND DISCUSSIONS}

\subsection{Descriptive statistics}

Table 2 provides summary statistics about index values - means, minimums, maximums, mean, standard deviations (SD),

Table 2. Descriptive statistics

\begin{tabular}{|c|c|c|c|c|c|c|c|c|}
\hline Indices & $\begin{array}{l}\text { Sample } \\
\text { size }\end{array}$ & Minimum & Maximum & Mean & St. deviation & $\begin{array}{c}\text { Coefficient of } \\
\text { variation }\end{array}$ & Skewness & Kurtosis \\
\hline \multicolumn{9}{|c|}{ Whole period November 2005 to November 2018} \\
\hline MBI10 & 156 & $1,575.38$ & $10,057.77$ & $2,849.57$ & $1,663.70$ & $58.38 \%$ & 2.23 & 4.76 \\
\hline BELEX 15 & 156 & 380.83 & $3,283.62$ & 897.88 & 605.51 & $67.44 \%$ & 2.26 & 4.47 \\
\hline CAC40 & 156 & $2,702.48$ & $6,104.00$ & $4,405.70$ & 812.65 & $18.45 \%$ & -0.01 & -0.98 \\
\hline SLI & 156 & 665.13 & $1,531.84$ & $1,166.82$ & 203.42 & $17.43 \%$ & -0.2 & -0.85 \\
\hline \multicolumn{9}{|c|}{ Pre-crisis period November 2005 to November 2018} \\
\hline MBI10 & 21 & $2,617.76$ & $8,021.55$ & $4,667.50$ & $1,701.38$ & $36.45 \%$ & 0.95 & -0.18 \\
\hline BELEX15 & 21 & $1,028.27$ & $3,283.62$ & $1,919.51$ & 789.26 & $41.12 \%$ & 0.91 & -0.76 \\
\hline CAC40 & 21 & $4,930.18$ & $6,104.00$ & $5,459.75$ & 376.67 & $6.90 \%$ & 0.27 & -0.58 \\
\hline SLI & 21 & $1,097.6$ & $1,439.44$ & $1,273.48$ & 118.04 & $9.27 \%$ & 0.2 & -1.38 \\
\hline \multicolumn{9}{|c|}{ Crisis period August 2007 to November 2011} \\
\hline MBI10 & 52 & $1,787.52$ & $5,404.86$ & $2,707.54$ & 822.91 & $30.39 \%$ & 1.56 & 1.43 \\
\hline BELEX15 & 52 & 380.83 & 1,783 & 715.17 & 667.00 & $93.27 \%$ & 1.53 & 1.15 \\
\hline CAC40 & 52 & $2,702.48$ & $4,482.60$ & $3,625.40$ & 425.19 & $11.73 \%$ & 0.95 & 0.32 \\
\hline SLI & 52 & 665.13 & $1,082.24$ & 932.02 & 105.12 & $11.28 \%$ & 0.54 & 0.4 \\
\hline \multicolumn{9}{|c|}{ After-crisis period December 2011 until October 2018} \\
\hline MBI10 & 83 & $1,575.38$ & $3,564.50$ & $2,087.32$ & 534.96 & $25.63 \%$ & 1.62 & 1.87 \\
\hline BELEX15 & 83 & 480.06 & 773.37 & 651.54 & 75.38 & $11.57 \%$ & -0.33 & -0.94 \\
\hline CAC40 & 83 & $3,731.42$ & $5,520.50$ & $4,707.48$ & 489.83 & $10.41 \%$ & -0.31 & -0.79 \\
\hline SLI & 83 & $1,157.42$ & $1,531.84$ & $1,326.65$ & 100.29 & $7.56 \%$ & -0.73 & -0.05 \\
\hline
\end{tabular}


coefficient of variation, skewness, and evidenced by MBI10.

kurtosis.

MBI 10 has witnessed the highest variability and fluctuation, with a very high coefficient of variation slightly lower than the BELEX15 index, in contrast to CAC 40 and SLI that professed low variation during the entire observation period. The skewness of the distribution is strongly positive for MBI 10 and BELEX 15, whereas both European indices have negative low values. Kurtosis in the case of MBI 10 and BELEX 15 is positive and very high, indicating abnormal peaks in the distribution of the indices prices. While in the period of crises only SLI have lower Standard deviation and all indices have positive value of Skewness and Kurtosis, the MBI 10 and BELEX15 are greater than 1.

The Figure 1 illustrates the movement of the market indices over the entire analyzed time-frame. It clearly shows the dramatic drops of the stock markets indices in the period 2007-2008, with the sharpest decline

\subsection{Correlation}

Hypothesis 1: The correlation between Macedonian SE (represented by MBI10) and Belgrade SE (represented by BELEX15) is higher during the crisis in comparison with the pre- and post-crisis periods.

For the first hypothesis we were testing if the correlation between Macedonian SE (represented by MBI10) and Belgrade SE (represented by BELEX15) is higher during the crisis in comparison with the pre- and post-crisis periods. The results from the analysis allow us to confirm this hypothesis. The correlation between them increased during the crisis by a significant level. The post-crisis period is where we have recorded surprisingly low correlation between the markets probably driven by the time consumed by the Macedonian Stock Exchange to heal from the financial distress. Our findings are in line with the research of

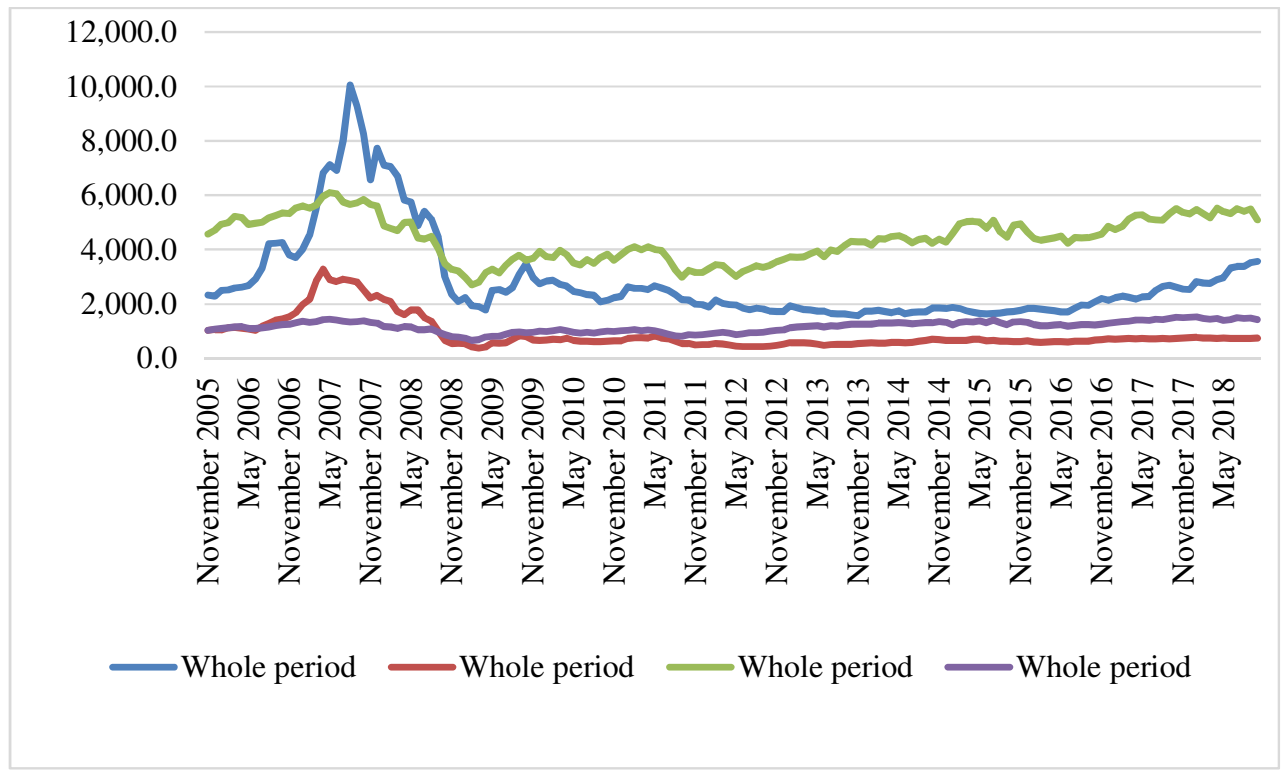

Sources: Macedonian SE, Belgrade SE, Euronext Paris SE and Six Swiss SE

Figure 1. Stock market indices 'values (November 2005-October 2018) 
Zdravkovski (2016). He stated that during the period of financial turbulence the relationship between the Balkan stock exchange markets is getting stronger. According to his research, the time of distress can seriously diminish the investor's ability to diversify their portfolios in the Balkans.

Hypothesis 2: The correlation between Macedonian SE (represented by MBI10) and Euronext Paris (represented by CAC40) is higher during the crisis in comparison with the pre- and post-crisis periods.

The second hypothesis assesses whether the correlation between Macedonian SE (represented by MBI10) and Euronext Paris (represented by CAC40) is higher during the crisis in comparison with the pre and postcrisis periods. This case was interesting because we can inspect whether the crisis impacts emerging and developed markets in a similar way. The correlation between those two markets increased during the crisis and based on that we can confirm this hypothesis. We can compare the finding with the conclusion reached by Tudor (2011) who stated that the relationship between the emerging CEE and the developed US stock market is higher during crisis as opposed to pre and post-crisis periods Similarly, Nistor et al. (2012) found that CAC40 index was strengthening the relationship with CEE indices during the crisis period.

Hypothesis 3: The correlation between Macedonian SE (represented by MBI10) and Six Swiss SE (represented by SLI) is higher during the crisis in comparison with the preand post-crisis periods.

The third hypothesis tested if the correlation between Macedonian SE

Table 3. MBI10-BELEX15 Regression Statistics

\begin{tabular}{llll}
\hline & \multicolumn{1}{c}{ Pre-crisis } & During crisis & Post-crisis \\
\hline Multiple R & 0.938088 & 0.986059 & 0.634581 \\
R Square & 0.880009 & 0.972312 & 0.402693 \\
Adjusted R Square & 0.873694 & $\mathbf{0 . 9 7 1 7 5 8}$ & 0.395319 \\
Standard Error & 627.2036 & 353.9906 & 382.6391 \\
Observations & 21 & 52 & 83 \\
\hline
\end{tabular}

Table 4. ANOVA: Regression analysis MBI10-BELEX15 in the pre-crisis period

\begin{tabular}{|c|c|c|c|c|c|}
\hline & $d f$ & $S S$ & $M S$ & $F$ & Significance $F$ \\
\hline Regression & 1 & 54816282 & 54816282 & 139.3453 & $3.42 \mathrm{E}-10$ \\
\hline Residual & 19 & 7474303 & 393384.4 & & \\
\hline Total & 20 & 62290585 & & & \\
\hline \multicolumn{6}{|c|}{ ANOVA: Regression analysis MBI10-BELEX15 in the crisis period } \\
\hline & $d f$ & $S S$ & $M S$ & $F$ & Significance $F$ \\
\hline Regression & 1 & $2.2 \mathrm{E}+08$ & $2.2 \mathrm{E}+08$ & 1755.839 & $1.2984 \mathrm{E}-40$ \\
\hline Residual & 50 & 6265469 & 125309.4 & & \\
\hline Total & 51 & $2.26 \mathrm{E}+08$ & & & \\
\hline \multicolumn{6}{|c|}{ ANOVA: Regression analysis MBI10-BELEX15 in the post-crisis period } \\
\hline & $d f$ & $S S$ & $M S$ & $F$ & Significance $F$ \\
\hline Regression & 1 & 7995408 & 7995408 & 54.60872 & $1.18 \mathrm{E}-10$ \\
\hline Residual & 81 & 11859425 & 146412.6 & & \\
\hline Total & 82 & 19854832 & & & \\
\hline
\end{tabular}


(represented by MBI10) and Six Swiss SE the 2008 Financial Crisis. Therefore, (represented by SLI) is higher during the spotting the first signs of a downturn and crisis in comparison with the pre- and post- having in store a pre-set response by the crisis periods. The correlation between those Swiss financial authorities explains the low two stock exchange markets was decreased correlation between the SLI and the other during crisis thus leading to a rejection of market indices.

this hypothesis. According to Newsweek (2008), Switzerland acted really fast at the onset of the financial disaster, setting a good example for other countries regarding how to best tackle crises. They made their economy fit for good and bad times before the start of

\section{CONCLUSION}

This paper scrutinizes the relationship between the Macedonian, Belgrade,

Table 5. MBI10-CAC40 Regression Statistics

\begin{tabular}{llll}
\hline & \multicolumn{1}{c}{ Pre-crisis } & During crisis & Post-crisis \\
\hline Multiple R & 0.888579 & 0.913236 & 0.594323 \\
R Square & 0.789572 & 0.834 & 0.353219 \\
Adjusted R Square & 0.778497 & 0.83068 & 0.345234 \\
Standard Error & 830.5883 & 866.7638 & 398.1705 \\
Observations & 21 & 52 & 83 \\
\hline
\end{tabular}

Table 6. ANOVA: Regression analysis MBI10-CAC40 in the pre-crisis period

\begin{tabular}{|c|c|c|c|c|c|}
\hline & $d f$ & $S S$ & $M S$ & $F$ & Significance $F$ \\
\hline Regression & 1 & 49182923 & 49182923 & 71.29231 & 7.45E-08 \\
\hline Residual & 19 & 13107663 & 689877 & & \\
\hline Total & 20 & 62290585 & & & \\
\hline \multicolumn{6}{|c|}{ ANOVA: Regression analysis MBI10-BELEX15 in the crisis period } \\
\hline & $d f$ & $S S$ & $M S$ & $F$ & Significance $F$ \\
\hline Regression & 1 & $1.89 \mathrm{E}+08$ & $1.89 \mathrm{E}+08$ & 251.2042 & $3.9 \mathrm{E}-21$ \\
\hline Residual & 50 & 37563970 & 751279.4 & & \\
\hline Total & 51 & $2.26 \mathrm{E}+08$ & & & \\
\hline \multicolumn{6}{|c|}{ ANOVA: Regression analysis MBI10-BELEX15 in the post-crisis period } \\
\hline & $d f$ & SS & $M S$ & $F$ & Significance $F$ \\
\hline Regression & 1 & 7013112 & 7013112 & 44.23567 & $3.15 \mathrm{E}-09$ \\
\hline Residual & 81 & 12841720 & 158539.8 & & \\
\hline Total & 82 & 19854832 & & & \\
\hline
\end{tabular}

Table 7. MBI10-SLI: Regression Statistics

\begin{tabular}{llll}
\hline & \multicolumn{1}{c}{ Pre-crisis } & During crisis & Post-crisis \\
\hline Multiple R & 0.875126 & 0.849138 & 0.515714 \\
R Square & 0.765845 & 0.721036 & 0.265961 \\
Adjusted R Square & 0.753521 & 0.715457 & 0.256899 \\
Standard Error & 876.1652 & 1123.622 & 424.18 \\
Observations & 21 & 52 & 83 \\
\hline
\end{tabular}


Table 8. ANOVA: Regression analysis MBI10-SLI in the pre-crisis period

\begin{tabular}{|c|c|c|c|c|c|}
\hline & $d f$ & $S S$ & $M S$ & $F$ & Significance $F$ \\
\hline Regression & 1 & 47704942 & 47704942 & 62.14288 & $2.08 \mathrm{E}-07$ \\
\hline Residual & 19 & 14585643 & 767665.4 & & \\
\hline Total & 20 & 62290585 & & & \\
\hline \multicolumn{6}{|c|}{ ANOVA: Regression analysis MBI10-BELEX15 in the crisis period } \\
\hline & $d f$ & $S S$ & $M S$ & $F$ & Significance $F$ \\
\hline Regression & 1 & $1.63 \mathrm{E}+08$ & $1.63 \mathrm{E}+08$ & 129.2347 & $1.81 \mathrm{E}-15$ \\
\hline Residual & 50 & 63126331 & 1262527 & & \\
\hline Total & 51 & $2.26 \mathrm{E}+08$ & & & \\
\hline \multicolumn{6}{|c|}{ ANOVA: Regression analysis MBI10-BELEX15 in the post-crisis period } \\
\hline & $d f$ & $S S$ & $M S$ & $F$ & Significance $F$ \\
\hline Regression & 1 & 5280613 & 5280613 & 29.34837 & $6.06 \mathrm{E}-07$ \\
\hline Residual & 81 & 14574220 & 179928.6 & & \\
\hline Total & 82 & 19854832 & & & \\
\hline
\end{tabular}

Euronext Paris and Six Swiss Stock Exchanges. For the purpose of discovering the possible impact of the 2008 Financial Crisis on the correlation between the chosen SE markets, the investigated time frame was divided in three sub-samples, particularly, pre-crisis period (November 2005 to July 2007), during the crisis (August 2007 to November 2011) and post-crisis period (December 2011 to October 2018). In order to understand the theoretical background behind this research problem, we explored and summarized many theoretical and empirical articles, studies and books. Consequently, we concluded that the vast majority of authors who analyzed the impact of the crisis on the relationship between the stock exchanges emphasized that the correlation between the SE is higher during the crisis (comparing to pre- and post-crisis periods) (Tudor, 2011; Zdravkovski, 2016; Alomari et al., 2018). Some of the results obtained from our research follow the exact same trend as the majority of researches, whereas some are rather contradictory.

We found that, in times of major financial turbulence, the Macedonian Stock Exchange tends to have higher correlation (comparing to pre- and post-crisis periods) with the emerging Belgrade and developed Euronext Paris Stock Exchanges. Subsequently, the correlation between the Macedonian Stock Exchange and Swiss Six Stock Exchange tends to decrease during the crisis (comparing to pre- and post-crisis periods). We found that Switzerland effectuated a fast and most effective response to the 2008 Financial Crisis comparing to the other countries. This fact may be an explanation of the decreased correlation between the Six Swiss SE main index SLI and the other three SE indices.

Overall, from the Macedonian investor's point of view, the ability to diversify the portfolio while investing in Belgrade or Euronext Paris SE during the periods of financial distress is extremely reduced. On the other side investing (during turbulent periods) in the Six Swiss SE could be an effective way to diversify the investor's portfolio.

The interdependency between financial markets has been at the focus of interest of the academic community in the last decades. Most researches cover the developed stock exchanges, and this research contributes to 
the academic theory examining the interrelation of developing stock exchanges from Balkan countries and developed European exchanges. The findings could be useful for regional investors, portfolio managers and market analysts in the process of decision making and portfolio construction.

\section{References}

Adeyeye, P.O., Aluko O.A., \& Migiro S.O. ( 2018). The global financial crisis and stock price behaviour: time evidence from Nigeria. Global Business and Economics Review, 20 (3), 373-387.

Aggarwal, R, Lucey, B., \& Muckley, C. (2003). Dynamics of equity market integration in Europe: evidence of changes over time and with events. Working Paper, Institute for International Integration Studies. Trinity College Dublin.

Alomari, M., Power, D.M., \& Tantisantiwong, N. (2018). Determinants of equity return correlations: A case study of the Amman Stock Exchange. Review of Quantitative Finance and Accounting, 50 (1), 33-66.

Angelovska, J. (2017). Long and ShortTerm Relationship between Macedonian and Croatian Stock Markets. Zagreb International Review of Economics \& Business, 20 (2), 11-20.

Chand, G.S., \& Thenmozhi, M. (2013). Do global stock market cues matter in forecasting stock returns in developed and developing markets? European Financial Management Association, 2013 Annual Meetings. Retrieved from http://www.efmaefm.org/0EFMAMEETING S/EFMA\%20ANNUAL\%20MEETINGS/20 1

Reading/papers/EFMA2013_0485_fullpaper .pdf

Dhal, S. (2009). Global Crisis and the Integration of India's Stock Market. Journal of Economic Integration, 24(4), 778-805.

Eiling, E., Gerard, B., Hillion, P., \& de Roon, F. A. (2012). International portfolio diversification: Currency, industry and country effects revisited. Journal of International Money and Finance, 31 (5), 1249-1278.

IPO Insights. (2009). IPO Insights: Comparing Global Stock Exchanges. Ernst \& Young, London. Retrieved from https://pdf4pro.com/fullscreen/ipo-insightscomparing-global-stock-exchanges-ey$539 \mathrm{c} 46 . \mathrm{html}$

Garcia, R., Mantilla-García, D., \& Martellini, L. (2014). A Model-Free Measure of Aggregate Idiosyncratic Volatility and the Prediction of Market Returns. Journal of Financial and Quantitative Analysis, 49 (56), 1133-1165.

Gradojević, N., \& Dobardžić, E. (2013). Causality between Regional Stock Markets: A Frequency Domain Approach. Panoeconomicus, 6 (5), 633-647.

Horvath, R., \& Petrovski, D. (2012). International Stock Market Integration: Central and South Eastern Europe Compared. Economic Systems, 37 (1), 8191.

Karagoz, K., \& Ergun, S. (2009). Stock Market Integration Among Balkan Countries. MIBES Proceedings 2009, 276286.

Kenourgios, D. and Samitas, A. (2011). Equity Market Integration in Emerging Balkan Markets. Research in International Business and Finance, 25 (3), 296-307.

Landau, S., \& Everitt, B. (2004). A handbook of statistical analyses using SPSS. Boca Raton: Chapman \& Hall/CRC. 


\title{
МЕЪУЗАВИСНОСТ ИЗМЕЪУ ТРЖИШТА У РАЗВОЈУ И \\ РАЗВИЈЕНИХ БЕРЗИ: СЛУЧАЈ МАКЕДОНСКЕ, БЕОГРАДСКЕ, "SIX" ШВАЈЦАРСКЕ И "ЕURONЕХТ" ПАРИСКЕ БЕРЗЕ
}

\author{
Dusica Stevcevska Srbinoska, Jadranka Mrsik, Egor Sekuloski, Tome Nenovski
}

\section{Извод}

Циљ рада је да се испита степен међузависности између развијених и тржишта акција у развоју. Проучавана је корелација македонског (МБИ10) берзанског индекса са београдском (БЕЛЕКС15), “Sіх” швајцарском (СЛИ) и Еуронекст париском (ЦАЦ40) берзом од новембра 2005. до октобра 2018. Да би се проценио утицај кризе на међуодносе између ових тржишта акција, анализирани период је подељен на три сегмента (пре кризе, током кризе и после кризе) и скуповеи података у подвргнути линеарној регресионој анализи. Резултати истраживања указују на повећану корелацију македонске са београдском и Еуронекст париском берзом и смањену корелацију са "Six" швајцарском у време финансијске кризе у поређењу са периодима пре и после кризе. Налази ове студије доприносе укупној слици односа између тржишта акција у време финансијске кризе. Штавише, истраживањем међуодноса између развијених европских берзи и оних у развоју, резултати сугеришу да је интеграција финансијског тржишта временски променљива.

Кључне речи: МБ, европска берза, финансијска криза, диверсификација

Liu, L. (2013). International Stock Markets interdependence: Are Developing Markets Same as Developed Markets? Journal of International Financial Markets Institutions and Money, 26 (c), 226-238.

Majid, M., \& Kassim, S. (2009). Impact of the 2007 US Financial Crisis on the Emerging Equity Markets. International Journal of Emerging Markets, 4 (4), 341357.

Nistor, C., Dumitriu, R., \& Stefanescu, R. (2012). Impact of the global crisis on the linkages between CAC 40 and indexes from CEE countries. Published in: Proceedings of the 2nd International Conference on Business Administration and Economics "People. Ideas. Experience", October 25-26, 2012, Reşiţa. 319-332.

Pagano, M., Röel, A., \& Zechner, J. (1999). The Geography of Equity Listing:
Why do European Companies List Abroad? Available at SSRN: https://ssrn.com/abstract=209313

Srikanth, P., \& Aparna, K. (2012). Global Stock Market Integration - A Study of Select World Major Stock Markets. Journal of Arts, Science and Commerce, 3 (1), 203-211.

PWC. (2015). Capital Markets Union: Integration of Capital Markets in the European Union, The PWC Market Research $\begin{array}{llllll}\mathrm{C} & \mathrm{e} & \mathrm{n} & \mathrm{t} & \mathrm{r} & \mathrm{e}\end{array}$, http://marketresearchcentre.pwc.lu/marketresearch-centre/docs/pwc-capital-marketsunion.pdf, 1-70.

Şahin, C. (2015). Co-integration Analysis between the Turkish Stock Market and its Balkan Hinterland Equivalents: Proof from the 2010-2015 Period. Journal of Economics and Social Studies, 6(1), 105-124.

Samadder, S. and Bhunia, A. (2018). 
Integration Between Indian Stock Market and Developed Stock Markets. Journal of Commerce \& Accounting Research, 7(1), 13-23.

Sharma, P. (2011). Asian emerging economies and United States of America: Do they offer a diversification benefit? Australian Journal of Business and Management Research, 1(4), 85-92.

Slimane, F.B., Mehanaoui, M., \& Kazi, I.A. (2013). How does the Financial Crisis Affect Volatility Behavior and Transmission among European Stock Markets? International Journal of Financial Studies, 1 (3), 81-101.

Syriopoulos, T., \& Roumpis, E. (2009). Dynamic Correlations and Volatility Effects in the Balkan Equity Markets. Journal of International Financial Markets Institutions and Money, 19 (4), 565-587.

Tennby, V., \& Ringström, M. (2015). Integration of European Equity Markets. (Bachelor thesis). Retreived from https:/gupea.ub.gu.se/bitstream/2077/41755 /1/gupea_2077_41755_1.pdf

Tudor, C. (2011). Changes in Stock Markets Interdependencies as a Result of the Global Financial Crisis: Empirical Investigation on the CEE Region. Panoeconomicus, 58 (4), 525-543.

Weisenthal, J. (2013). Here's When the Economic Crisis Actually Ended, 26 December [online] https://www.businessinsider.com/hereswhen-the-economic-crisis-actually-ended2013-12 (accessed 4 January 2015).

Zdravkovski, A. (2016). Stock Market Integration and Diversification Possibilities during Financial Crisis: Evidence from Balkan Countries. MPRA Paper No.72182, University Library -of Munich, Germany. 